tions in their children. In: Albermane, ed. The needs of parents and their children. Health Promotion Research Trust (in press).

${ }^{4}$ Chamberlain R, Chamberlain G, Howlett B, Claireaux A British births 1970. Vol 1: The first week of life. London: Heinneman, 1975.

J I POLLOCK Department of Child Health, Royal Hospital for Sick Children, St Michael's Hill, Bristol BS2 8BJ

\section{Brittle or battered?}

Sir,

My attention has been drawn to correspondence about this subject. There is reference to an article in which I reported study of a series of children with osteogenesis imperfecta with special reference to the occurrence of metaphyseal fractures. ${ }^{1}$

In his letter Dr Blumenthal states that 'metaphyseal fractures are a feature of both abuse and brittle bones'. This is true but needs qualification. In non-accidental injury the bones appear grossly normal and the metaphyseal fractures are often numerous. In osteogenesis imperfecta fractures of this type are infrequent and rarely number more than one or two. They were only seen in my series where there was gross abnormality of the skeleton and the diagnosis of the presence of a systemic bone disease was apparent at a glance.

To quote my last sentence, 'Confusion with non-accidental injury did not occur'.

\footnotetext{
References

1 Astley R. Metaphyseal fractures in osteogenesis imperfecta. $\mathrm{Br}$ J Radiol 1979;52:441-3.

2 Blumenthal I. Brittle or battered. Arch Dis Child 1989;64:176.
}

R Astley

The Children's Hospital, Birmingham B16 8ET

\section{Somatostatin analogue in short term management of hyperinsulinism}

Sir,

We are interested by the report of Kirk et al of the use of somatostatin analogue for the short term management of hyperinsulinism in which a fall in glucose requirement of 4-6 mg/kg/minute was seen. ${ }^{1}$ We have previously reported similar success, in the short term control of hyperinsulinism in an infant with nesidoblastosis, using growth hormone twice daily by subcutaneous injection. ${ }^{2} \mathrm{~A}$ fall in glucose requirement of $5.5 \mathrm{mg} / \mathrm{kg} /$ minute was seen. The effect of growth hormone in the treatment of hypoglycaemia is reported elsewhere. ${ }^{34}$
At the time of our report further studies of this use of growth hormone were precluded by the withdrawal of pituitary growth hormone after reports of CreutzfeldtJakob disease. Now that a growth hormone produced by recombinant DNA technology is available, however, the choice of growth hormone over a somatostatin analogue has advantages

Somatostatin has a very broad range of endocrine activity, ${ }^{1}$ with unwanted effects upon other endocrine axes that do not appear to be produced by growth hormone. Furthermore, on simply practical grounds growth hormone, unlike somatostatin, is available in most regional centres.

In the infant with hyperinsulism, when it is necessary to temporise before surgery, we believe that growth hormone may be preferable, and its use certainly merits further study.

\section{References}

1 Kirk JMW, Di Silvio L, Hindmarsh PC, Brook CGD. Somatostatin analogue in short term management of hyperinsulinism. Arch Dis Child 1988;63:1493-4.

2 Hocking MD, Newell SJ, Rayner PHW. Use of huınan growth hormone in treatment of nesidoblastosis in a neonate. Arch Dis Child 1986;61:706-7.

${ }^{3}$ Soyka LF, Molliver M, Crawford JD. Idiopathic hypoglycacmia of infancy, treatment with human growth hormonc. Lancet $1964 ; \mathbf{i}: 1016$.

${ }^{4}$ Ernesti M, Mitchell ML, Raben MS, Gilboa Y. Control of hypoglycaemia with diazoxide and human growth hormone. Lancet 1965;i:628-30.

$$
\begin{array}{r}
\text { S J Newell, }{ }^{*} \text { M D Hocking, } \dagger \text { and } \\
\text { P H W RAYNER* } \\
\text { *University of Birmingham, } \\
\text { Institute of Child Health, } \\
\text { Francis Road, } \\
\text { Birmingham Bl6 8ET } \\
\text { †Children's Hospital, } \\
\text { Ladywood Middleway, } \\
\text { Birmingham B16 8ET }
\end{array}
$$

\section{Disialotransferrin developmental deficiency syndrome and olivopontocerebellar atrophy}

Sir,

I read with great interest the paper of Kristiansson et al about disialotransferrin developmental deficiency syndrome. ${ }^{1}$ I would like to draw attention to the remarkable similarity between this syndrome and a condition recently reported in two siblings as olivopontocerebellar atrophy with neonatal onset. ${ }^{2}$ Common features included failure to thrive, hypotonia, developmental delay, joint restrictions, pericardial effusions, mild non-progressive liver disease, retinal dystrophy, and cerebellar hypoplasia.

Moreover there was thyroxine binding globulin deficiency in the patients reported by Harding et $a l^{2}$ and although serum concentrations of thyroxine binding 
globulin were not reported in the paper of Kristiansson et al thyroxine binding globulin deficiency was a constant feature in our patients who presented with a closely related condition. ${ }^{3}$ The only difference was the clinical course of the condition, which was fatal in both patients (at 7 and 23 months) of Harding et al whereas the patients of Kristiansson et al and those reported by us were all alive (age 3 to 21 years).

I therefore recommend a search for defects in glycoprotein metabolism (particularly in the processing and synthesis of the carbohydrate moiety) in patients with olivopontocerebellar atrophy. A valuable screening method for this purpose is the carbohydrate deficient transferrin test devised by Stibler et al. ${ }^{4}$

\section{References \\ ${ }^{1}$ Kristiansson B, Andersson M, Tonnby B, Hagberg B. Disialo- transferrin developmental deficiency syndrome. Arch Dis Child 1989;64:71-6. \\ 2 Harding BN, Dunger DB, Crant DB, Erdohazi M. Familial olivopontocerebellar atrophy with neonatal onset: a recessively inherited syndrome with systemic and biochemical abnormalities. J Neurol Neurosurg Psychiatry 1988;51:385-90. \\ 3 Jaeken J, Eggermont E, Stibler H. An apparent homozygous $\mathrm{X}$-linked disorder with carbohydrate-deficient serum glyco- proteins. Lancet 1987;i:1938. \\ 4 Stibler H, Borg S, Joustra M. Micro anion exchange chromato- graphy of carbohydrate-deficient transferrin in serum in relation to alcohol consumption. Alcohol, Clinical and Experimental Research 1986;10:535-44.}

J JAEKEN Department of Paediatrics, University Hospital Gasthuisberg, 49 Herestraat, B-3000 Leuven, Belgium

\section{Clostridium difficile in an oncology unit}

Sir,

Brunetto et al describe a cluster of patients with Clostridium difficile and conclude that an outbreak had occurred.' However, I wonder whether this might, at least in part, have been a pseudo-outbreak. A previous paper reported a cluster of cases, but serotyping of the isolates showed that four strains were circulating and other investigations showed the cause of the outbreak to have been a virus rather than $C$ difficile. ${ }^{2}$

In the incident reported by Brunetto et al only two of 21 patients had severe symptoms and in only 18 of $31(58 \%)$ episodes of $C$ difficile associated with diarrhoea was toxin detected. Colonisation rates almost as high as $40 \%$ have been reported for $C$ difficile in oncology units in the absence of overt problems, ${ }^{3}$ hence positive cultures in the absence of detectable toxin is of questionable significance.

Although the epidemic curve in the current incident appears most impressive, could the rise in incidence merely represent an increased level of investigation for $C$ difficile rather than a genuine increase in prevalence? Typing the isolates by one or more methods might have strengthened or refuted the interpretation the authors place on their data.

\section{References}

1 Brunetto AL, Pearson ADJ, Craft AW, Pedler SJ. Clostridium difficile in an oncology unit. Arch Dis Child 1988;63:979-81.

2 Toma S, Lesiak G, Magus $M$, Lo H-L, Delmée $M$. Serotyping of Clostridium difficile. J Clin Microbiol 1988;26: 426-8.

${ }^{3}$ Morris JG, Jarvis WR, Nunez-Montiel OL, et al. Clostridium difficile colonization and toxin production in a cohort of patients with malignant haematological disorders. Arch Intern Med 1984;144:967-9.

J W Hartley

Department of Medical Microbiology, Withington Hospital, West Didsbury, Manchester M20 8LR

\section{Dehydration fever in the neonate-a common phenomenon?}

Sir,

Rises in temperature are seen occasionally on the third to fourth day of life in infants who are otherwise well, and overheating and sepsis as causes of fever must be excluded. ${ }^{1}$ Dehydration is perhaps an infrequently recognised cause of fever in the newborn period.

\section{Case report}

A boy was born at term after a normal pregnancy and labour weighing $4000 \mathrm{~g}$. The initial examination at 36 hours of age showed a temperature of $37.7^{\circ} \mathrm{C}$ but he was normal otherwise. He was breast fed and remained well until the age of 3 days when he developed a tachycardia and irritability and was found to have a temperature of $38.1^{\circ} \mathrm{C}$ that rose rapidly to $39 \cdot 2^{\circ} \mathrm{C}$. Investigations showed a serum sodium concentration of $153 \mathrm{mmol} / \mathrm{l}$ and a metabolic acidosis; plasma glucose and creatinine, full blood count, a chest radiograph, and cranial ultrasound scan were normal. Urine and blood cultures were sterile. After resuscitation with plasma the temperature fell to $37.9^{\circ} \mathrm{C}$. The infant fed ravenously from the bottle. At discharge the plasma sodium concentration and urine osmolality had returned to normal and his weight had risen from $3620 \mathrm{~g}$ to $3810 \mathrm{~g}$ (figure).

The clinical features and results of investigations supported dehydration and excluded sepsis and overheating as the cause of this infant's fever. The dehydration was due probably to an inadequate intake of milk. Dehydration fever is seen most commonly in large breast fed babies whose milk intake is poor or in infants exposed to high environmental temperatures, with rises in temperatures to between 37.8 and $40^{\circ} \mathrm{C} .{ }^{2}$ Infants appear unhappy and may lose approximately $10 \%$ of their birth weight. Diagnosis 